\title{
Channa royi (Teleostei: Channidae): a new species of snakehead from Andaman Islands, India
}

\author{
J. PRAVEENRAJ ${ }^{1}$, J. D. M. KNIGHT ${ }^{2}$, R. KIRUBA-SANKAR ${ }^{1}$, BENI HALALLUDIN $^{3}$, \\ J. J. A. RAYMOND ${ }^{1}$ AND V. R. THAKUR ${ }^{1}$ \\ ${ }^{1}$ Fisheries Science Division, ICAR-Central Island Agricultural Research Institute, Port Blair - 744101 \\ Andaman and Nicobar Islands, India \\ ${ }^{2}$ Flat 'L', Sri Balaji Apartments, $7^{\text {th }}$ Main Road, Dhandeeswaram, Velachery, Chennai - 600 042, Tamil Nadu, India \\ ${ }^{3}$ JI. Raya Puncak Cibogo II, Rt. 2/6 NO.119, Bogor 16770, Indonesia \\ e-mail:jpr948@gmail.com
}

\section{ABSTRACT}

\begin{abstract}
A new species of snakehead fish Channa royi sp. nov., has been described based on 21 specimens collected from the South, Middle and North Andaman Islands, India. It is distinguished from all its congeners by a greenish-grey dorsum, pale brown to black pectoral fin with 2-3 inconspicuous semicircular bands, a series of 7-9 obliquely-arranged, saddle-like, dark olive to grey oblique streaks on green background on upper half of the body, 42-45 pored lateral-line scales, 12-13 branched caudal rays, 6-7 pre-dorsal scales, 43 vertebrae, two rows of teeth on the lower jaw, an outer row of numerous minute slender, pointed teeth and single inner row of large uniform sized teeth without any large canine like teeth on the anterior fourth of the lower jaw. Phylogenetically $C$. royi sp. nov. is closely related to C. harcourtbutleri, with a genetic distance (K2-P) of 2.4-2.8\%, but morphologically differs in having greater inter-orbital width, fewer pelvic-fin rays (5vs. 5-7, mode 6); fewer caudal-fin rays (ii- i, 10-12, i-ii vs. ii, 15, ii); more pre-dorsal scales (6-7 vs. 4) and fewer mid row lateral-line scales (9-13 vs. 15-16). Though Channa royi sp. nov. is a part of C. gachua species-group, it differs from the topotypic C. gachua from Bengal with higher pair-wise sequence distance of 20.7-22.8\%.
\end{abstract}

Keywords: Andaman Islands, Channa gachua, Channa limbata, Channa royi sp. nov., Channidae, Snakeheads

\section{Introduction}

Snakeheads of the family Channidae are mostly distributed in tropical Africa, parts of the Middle East and Asia. These are found to exist in a wide variety of freshwater habitats ranging from hill streams to derelict swamps (Courtenay and Williams 2004; Geetakumari and Vishwanath, 2011). At present, the family Channidae consists of 44 valid species. There are 17 valid species of Channa reported from India; 24 species from Southeast Asia and three species under the genus Parachanna from Africa (Conte-Grand et al., 2017; Fricke et al., 2018; Praveenraj et al., 2018a, b; Adamson and Britz, 2018). The species-level diversity of the family Channidae is still not fully known (Britz, 2013), especially for species groups like that of C. gachua, which was proposed by Britz (2008) based on the molecular studies of Li et al. (2005). The species in this group have a body colouration from grey to greyish-brown, ventral region being white or dirty white and the anal, caudal and dorsal fins are iridescent green or blue with an orange margin ( $\mathrm{Ng}$ and Lim, 1990; Lee and $\mathrm{Ng}, 1994)$, pectoral fins with a varying number of dark and light semicircular bands (Britz, 2008) and two large cycloid scales on each side of lower jaw (Vishwanath and Geetakumari, 2009). The present study describes a new species of Channa belonging to C. gachua species-group, collected from the South, Middle and North Andamans.

\section{Materials and methods}

Study area and sampling

Specimens were collected from four locations in the Andaman group of islands, India viz., streams in Mannarghat $\left(11^{\circ} 45^{\prime} 43.45^{\prime \prime} \mathrm{N} ; 92^{\circ} 43^{\prime} 2.03 " \mathrm{E}\right)$, Garacharma $\left(11^{\circ} 36^{\prime} 53.93\right.$ "N; $\left.92^{\circ} 43^{\prime} 5.00^{\prime \prime E}\right)$ and Goalghar $\left(11^{\circ} 39^{\prime} 45.49^{\prime \prime N} ; 92^{\circ} 44^{\prime} 5.15^{\prime \prime} \mathrm{E}\right)$ of South Andaman District, Nimbudera (1243'21.99"N; 92 $\left.2^{\circ} 3^{\prime} 11.00^{\prime \prime E}\right)$ in Middle Andaman District. A few specimens were also collected from Diglipur fish market, North Andaman District. Topotypes of the comparative specimens were purchased through the aquarium traders and a few others were also collected with the help of collaborating institutes. The specimens were fixed in $10 \%$ formalin and subsequently preserved in $70 \%$ alcohol for further studies.

Abbreviations: ZSI/ANRC-Zoological Survey of India, Andaman and Nicobar Regional Centre, India; ZSI FF-Zoological Survey of India, Freshwater Fish 
collections, Kolkatta, India; CIARI/FF-ICAR-Central Island Agriculture Research Institute, Freshwater Fish collections, India; MNHN-Museum National d'Histoire Naturelle, Paris; MCSNG-Museo Civico di Storia Naturale "Giacomo Doria", Italy; MKC-Marcus Knight Collections, Chennai, India.

\section{Meristics, morphometry and osteology}

Methods for taking counts and measurements followed Musikasinthorn (1998) and Britz (2008). Measurements were made with digital calipers to the nearest $0.1 \mathrm{~mm}$. Subunits of the body parts are presented as percent of standard length (SL) and subunits of the head are presented as percent of head length (HL). Numbers in parenthesis after a count denotes the frequency of that count. Data from Ng et al. (1999), Musikasinthorn (2000) and Britz (2008) were used for comparison. The original descriptions of various synonyms of C. gachua and counts taken from type specimen photographs were used in the study. Osteological preparations were made following staining procedure of Taylor and Van Dyke (1985) and osteological nomenclature from Murray (2012). Vertebrae were counted from one specimen of the new species which was cleared and stained for osteology. Teeth and ceratobranchial were cleared and stained from a single specimen each of $C$. stewartii, C. melanostigma, C. gachua and C. limbata. Photographs of the stained bones were taken with an Olympus SP570 UZ digital camera using super-macro mode.

\section{Genetic analysis}

Clippings from right side pectoral fin and muscle tissue dissected from the right side of the body were collected from 13 sampled specimens: CIARI/FF-10-11 from Goalghar, South Andaman; CIARI/FF-13-15 from Garacharma, South Andaman; CIARI/FF-17-18 from North Andaman; CIARI/FF-19-20 from Middle Andaman; CIARI/FF-21-24 from Mannarghat, South Andaman. Two topotype specimens of C. gachua from Bengal (CIARI/ FF-25-27) and one topotype of C. limbata from West Java Bogor and Indonesia (CIARI/FF-34) were also barcoded for comparison. DNA was extracted using Qiagen blood and tissue kit from fin clippings and muscle tissues. DNA amplification of the cytochrome $\mathrm{C}$ oxidase subunit I (cox1) gene was done using the species specific primer (COX Forward-CTCGACTAATCACAAAGACATCG and COX Reverse-GGT GCCCAAAGAATCAGAAT) designed using the PRIMER3 software (Koressaar and Remm, 2007; Untergasser et al., 2012). PCR amplification reaction was performed in a final volume of $50 \mu \mathrm{l}$ PCR mix consisting of $5 \mu 1$ of PCR buffer, $5 \mu 1$ of $2 \mathrm{~mm}$ dNTPs, $4 \mu \mathrm{l}$ of $\mathrm{MgCl}_{2,}, 2 \mu \mathrm{l}$ each of $10 \mathrm{pmol}$ forward and reverse primers, $2 \mu \mathrm{l}$ of dimethyl sulphoxide (DMSO), $2 \mu \mathrm{l}$ of 5 units $\mu \mathrm{l}^{-1}$ Taq polymerase and $26 \mu \mathrm{l}$ nuclease free water. PCR reaction was carried out in a thermocycler (Bio-Rad, USA) following the conditions as described by Lakra et al. (2010). The amplified PCR products were sequenced using COX-F and COX-R primers in ABI 3500 DNA analyser (Shrimpex Biotech Pvt. Ltd., Chennai). The homology of the generated sequences were analysed using the Basic Local Alignment Search Tool (BLAST) (Altschul et al., 1990). The sequences were trimmed by CLC sequence viewer ver. 8 (QIAGEN) and submitted in the National Center for Biotechnology Information (NCBI) GenBank database.

Gene sequences were aligned using MUSCLE (Multiple Sequence Alignment with High Accuracy and High Throughput) (Edgar, 2004). The genetic distance between the Channa spp. sequences was determined by the Kimura 2-parameter (K2-P) model (Kimura, 1980) in the software program MEGA7 (Molecular Evolutionary Genetics Analysis) (Kumar et al., 2016). The best fit nucleotide substitution model was selected from 24 models, based on the one with the lowest BIC scores (Bayesian Information Criterion), which was considered to describe the best substitution pattern (Nei and Kumar, 2000). The phylogenetic tree was constructed based on the maximum likelihood fits in MEGA7. Reliability of the phylogenetic tree was estimated using bootstrap values run for 1000 iterations.

\section{Results}

Channa royi, sp. nov. Praveenraj \& Knight (Fig. 1, 2, 3)

Common name: Andaman emerald snakehead

Holotype: ZSI/ANRC-12467, 1 ex., 108.8 mm SL (Fig. 1, 2; Table 1 ), Mannarghat, South Andaman, India

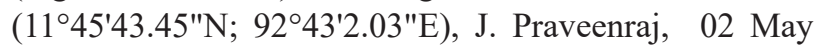
2015 ,

Paratypes: ZSI/ANRC-12468, 1 ex., 44.6 mm SL, same data as holotype; ZSI FF 7662, 2 ex., 160.3-170.9 mm SL, Diglipur fish market, North Andaman, J. Praveenraj, 17 February 2017; ZSI FF 7663, 1 ex., $138.3 \mathrm{~mm}$ SL, pond located near a stream, Nimbudera, Middle Andaman, (1243'21.99"N; 9253'11.00"E), J. Praveenraj, 17 February 2017; CIARI/FF-08-12, 5 ex., 121.7-160.0 $\mathrm{mm} \quad \mathrm{SL} \quad(139.3$ and $145.3 \mathrm{~mm}$ SL, GenBank Acc. No. KY214142, KY214136), a stream draining into a municipal canal, Goalghar, South Andaman (11॰39'45.49"N; 9244'5.15"E), J. Praveenraj, 25 January 2016; CIARI/FF-13-15, 3 ex., 108.3-118.4 mm SL, GenBank Acc. No. KY214138, KY562577, KY562578), a stream passing through ICAR-CIARI, 


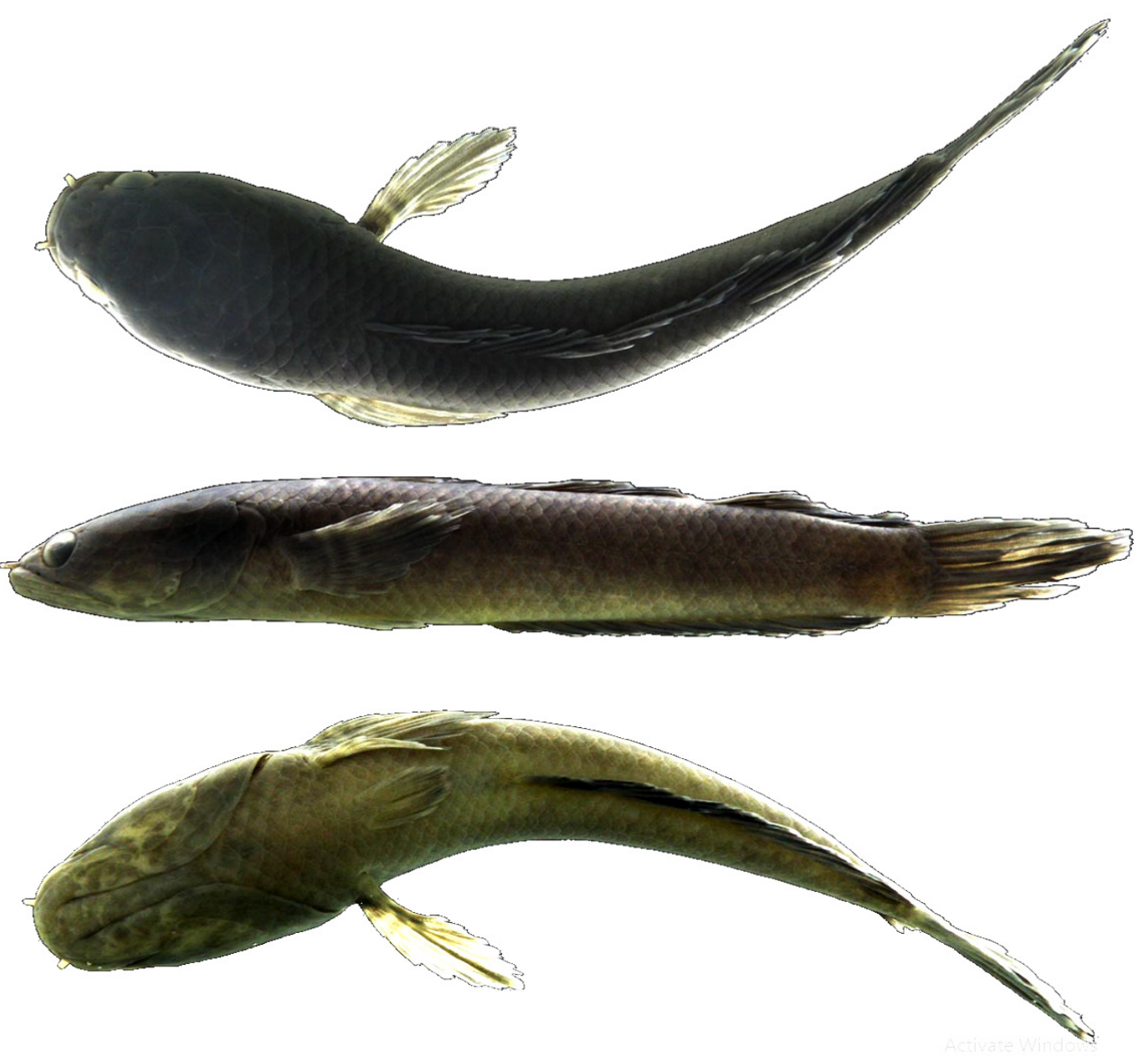

Fig. 1. Channa royi sp. nov. holotype, ZSI/ANRC-12467, 108.8 mm SL, South Andaman (Photo credit: Dr. J.D.M. Knight)

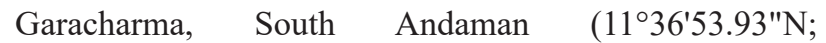
92 43'5.00"E), J. Praveenraj, 21 January 2017; CIARI/ FF-17-18, 2 ex., 170.2-180.9 mm SL (GenBank Acc. No. KY863530, KY863529), same data as North Andaman specimens; CIARI/FF-19-20, 2 ex., 163.5-190.3 mm SL (GenBank Acc. No. KY863528, KY863527), same data as Middle Andaman specimens; CIARI/FF-21-23, 3 ex., 128.5-142.2 mm SL (128.5, 141.5 and $142.2 \mathrm{~mm} \mathrm{SL}$, GenBank Acc. No. KY214137, KY562575, KY562574), Mannarghat hill stream, South Andaman $\left(11^{\circ} 45^{\prime} 43.45^{\prime \prime N}\right.$; 92॰43'2.03"E), J. Praveenraj, 1 February 2017. CIARI/FF24, 1 ex., $99.2 \mathrm{~mm} \mathrm{SL}$, same data as holotype (cleared and stained for osteology, GenBank Acc. No. KY562576).

Diagnosis: Channa royi sp. nov. is distinguished from all other species of the genus Channa belonging to the Channa gachua species-group by a combination of following characters: unique greenish-grey dorsum; upper half of body with a series of 7-9 obliquely-arranged, saddle-like, dark olive to grey oblique streaks on green background; throat with marbled pattern; 34-38 dorsal-fin rays; 22-25 anal-fin rays; $42-45$ pored scales on body; 1-3 scales on caudal fin base; $3 \frac{1}{2}$ scales above lateral line and $6 \frac{1}{2}$ scales below lateral line; 6-7 pre-dorsal scales; 43 vertebrae; two rows of teeth on the lower jaw, single outer row of numerous minute slender pointed teeth and single inner row of enlarged uniform teeth without any large canine like teeth on anterior-fourth of the lower jaw; two rows of teeth on palatine; outer row with numerous minute sharp slender teeth and inner row with 4 to 6 large canine like teeth and pectoral fins pale brown to black in adults with 2-3 pale grey to black inconspicuous semicircular bands.

Description: Body elongate and round in cross section anteriorly, its width a little less than its depth, gradually becoming laterally compressed towards caudal peduncle. Dorsal profile of head gently curved anteriorly, ventral profile almost straight. Caudal peduncle deep, its depth greater than its length. Head large, length 3.0-3.6 times in SL, dorso-ventrally flattened, its widest portion between 
Table 1. Morphometric data of Channa royi sp. nov. $(\mathrm{n}=21)$ including those of the holotype

\begin{tabular}{llll}
\hline Parameters & Holotype & Range & Mean \pm SD \\
\hline Standard length, SL (mm) & 108.8 & $44.6-190.3$ & $139.2 \pm 33.2$ \\
\hline In \% SL & & & \\
\hline Head length & 32.0 & $27.5-34.1$ & $30.3 \pm 1.7$ \\
Head depth & 14.7 & $13.0-18.5$ & $15.6 \pm 1.1$ \\
Head width & 19.3 & $17.3-20.8$ & $18.7 \pm 1.0$ \\
Body depth & 16.5 & $14.3-19.5$ & $17.3 \pm 1.2$ \\
Body width & 15.2 & $10.7-15.7$ & $13.5 \pm 1.4$ \\
Pre-dorsal length & 36.9 & $32.7-39.0$ & $34.9 \pm 1.7$ \\
Pre-anal length & 51.1 & $49.2-55.4$ & $52.4 \pm 1.8$ \\
Pre-pectoral length & 32.2 & $28.5-34.8$ & $31.9 \pm 1.6$ \\
Pre-pelvic length & 35.3 & $32.4-37.8$ & $35.1 \pm 1.4$ \\
Dorsal fin base length & 56.8 & $56.3-66.8$ & $60.6 \pm 2.6$ \\
Anal fin base length & 36.6 & $33.8-44.0$ & $39.5 \pm 2.8$ \\
Pectoral fin length & 20.8 & $17.3-22.0$ & $19.5 \pm 1.5$ \\
Pelvic fin length & 10.2 & $7.8-11.0$ & $9.3 \pm 0.9$ \\
Caudal peduncle length & 8.6 & $5.1-9.2$ & $7.8 \pm 1.0$ \\
Caudal peduncle depth & 9.8 & $9.8-13.0$ & $11.5 \pm 0.8$ \\
Snout length & 7.0 & $5.3-7.5$ & $6.3 \pm 0.5$ \\
Eye diameter & 5.1 & $3.7-8.1$ & $4.6 \pm 0.9$ \\
Pre-orbital depth & 8.1 & $5.9-10.1$ & $8.1 \pm 1.0$ \\
Post-orbital depth & 11.4 & $8.4-12.6$ & $10.7 \pm 1.0$ \\
Post-orbital length & 20.8 & $18.0-22.1$ & $20.5 \pm 1.0$ \\
Inter-orbital width & 8.8 & $8.3-9.6$ & $8.9 \pm 0.4$ \\
Upper jaw length & 13.1 & $9.2-13.8$ & $11.5 \pm 1.2$ \\
\hline In \% head length & & & \\
\hline Snout length & 40.9 & $33.3-42.6$ & $37.9 \pm 2.9$ \\
Eye diameter & 16.0 & $12.6-23.7$ & $15.0 \pm 2.2$ \\
Head depth & 46.1 & $38.2-63.1$ & $51.7 \pm 5.2$ \\
Head width & 60.4 & $52.0-69.1$ & $61.9 \pm 4.6$ \\
Pre-orbital depth & 25.2 & $20.2-32.6$ & $26.7 \pm 3.7$ \\
Post-orbital depth & 35.8 & $30.1-43.6$ & $35.4 \pm 3.1$ \\
Post-orbital length & 65.0 & $63.2-71.7$ & $67.8 \pm 2.0$ \\
Inter-orbital width & 27.5 & $26.5-34.1$ & $29.5 \pm 1.9$ \\
Upper jaw length & 40.9 & \\
\hline & & & \\
\hline
\end{tabular}

eye and opercle. Eyes small, located anteriorly on head, closer to tip of snout than to distal opercular margin. Mouth large, oblique, angle of gape extending beyond the posterior margin of the eye. Lower jaw projecting slightly beyond upper jaw, lips fleshy. Fifth ceratobranchial slender, with numerous long sharp inward pointing teeth (Fig. 4a). Both jaws with multiple rows of sharp and pointed teeth. Two rows of teeth on the palatine, outer row with numerous minute sharp slender teeth and inner row with 4 to 6 large canine like teeth (Fig. 4b). Two rows of teeth on lower jaw, an outer row of numerous minute slender pointed teeth and single inner row of enlarged uniform teeth without any large canine like teeth on anterior-fourth of lower jaw (Fig. 4c). Vomer with 6 small sharp, pointed teeth and 4 canine-like teeth.

Total pored scales $42(7)^{*}$ (numbers in parenthesis after a count denotes the frequency of that count and asterisk denotes count for holotype), 43 (12), 44 (1) and 45 (1); mid row pored scales 12 (5) or $13(16)^{*}$; lower row pored scales $29(3)^{*}, 30$ (16), 31 (1), 33 (1); scales on caudal fin base $1(12)^{*}, 2$ (6), 3 (3); transverse scales $3 \frac{1}{2} / 1 / 6^{1 / 2}(21)$; pre-dorsal scales $6(1), 6^{1 / 2}(2), 7(18)^{*}$; circumpeduncular scales 24 (8), $26(13)^{*}$; pre-pelvic scales $10(18)^{*}, 10 \frac{1}{2}(3)$. Fin rays: dorsal $34(2), 35(7)^{*}, 36(6)$, 37 (2), 38 (4); anal 22 (2), 23 (6), 24 (7)* 25 (6); pectoral 14 (2), 15 (19)*; caudal $12(1), 13(20)^{*}$; pelvic 5 (21). Vertebrae 43 (39 abdominal +4 caudal) (1).

Colouration: Live specimens (Figs. 2a, 3) appears greenish-grey, top of head and opercular region dark green. Dorsum greenish, gradually becoming pale grey towards the abdomen, upper half of body with series of 7-9 obliquely-arranged, saddle-like dark olive to grey oblique streaks on green background. Throat region marbled with white blotches on grey background. Dorsal fin is bluish green in colour with thin orange outer margin. Anal fin bright-blue in base and darker towards margin with a paleorange colour towards distal region. Caudal fin membrane bluish-green with bright-green rays and a thin orange border. Pectoral fins pale brown to black in mature adults (> $150 \mathrm{~mm} \mathrm{SL}$ ) with 2-3 inconspicuous black to pale grey semicircular bands (Fig. 3 a, b). Pelvic fins grey with a white margin. Sclera on the eyes red with a black patch below orbit. Juvenile specimen $(<50 \mathrm{~mm} \mathrm{SL})$ pale greyish cream in colour with numerous black spots scattered along the head, opercle and body. Dorsal and anal fins hyaline with numerous large, dark-grey elongated blotches. Caudal fin hyaline with 5-6 vertical pale grey bars. Pectoral fins hyaline, with two inconspicuous creamy white semicircular bands (Fig. 2b).

In alcohol preserved specimens (Fig. 1), dorsum, sides of head and body uniformly dark greyish-brown gradually becoming lighter towards the throat and abdomen. Dorsal, anal and caudal fins dark-grey with a thin white margin. Pectoral fins dark-grey with two white semicircular bands. Pelvic fins grey with a white margin.

Etymology: The species is named after Dr. S. Dam Roy, in appreciation for his immense encouragement and support for the exploration of the freshwater fishes of Andaman and Nicobar Islands. The species name is formed as a noun in the masculine genitive singular. The common 


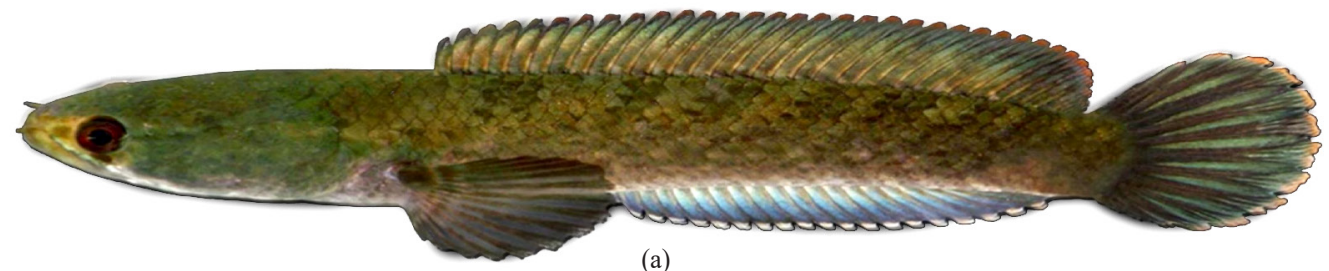

(a)
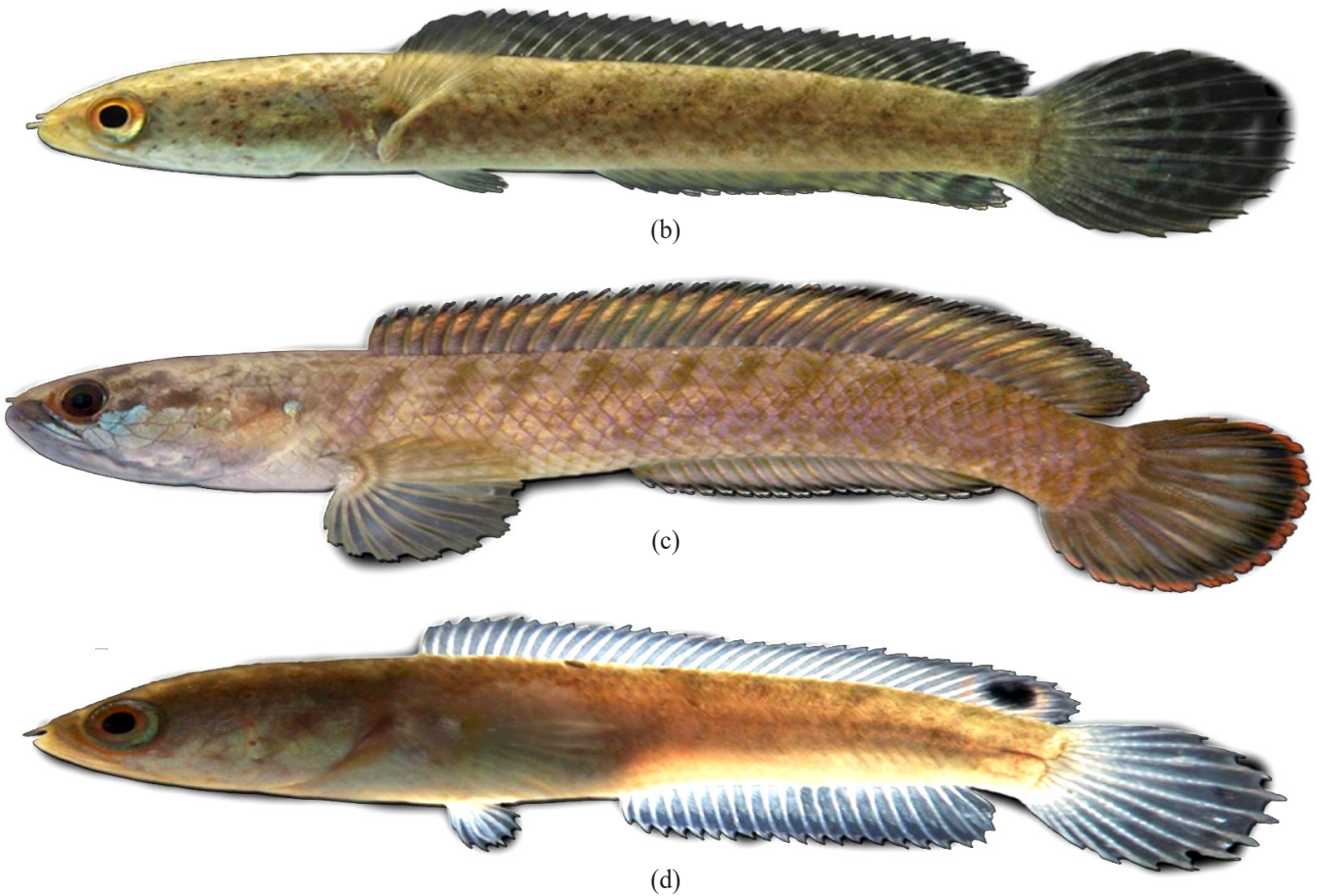

(d)

Fig. 2. (a). Channa royi sp.nov. holotype prior to preservation (ZSI/ANRC-12467), (b). Juvenile specimen of C. royi, uncatalogued, $44.6 \mathrm{~mm} \mathrm{SL}$, (c). Channa gachua (CIARI/FF-27), $94.33 \mathrm{~mm} \mathrm{SL}$, (d). Juvenile specimen of Channa gachua (MKC 191), $46.2 \mathrm{~mm}$ SL. (Photo credits: Dr. J. D. M. Knight)

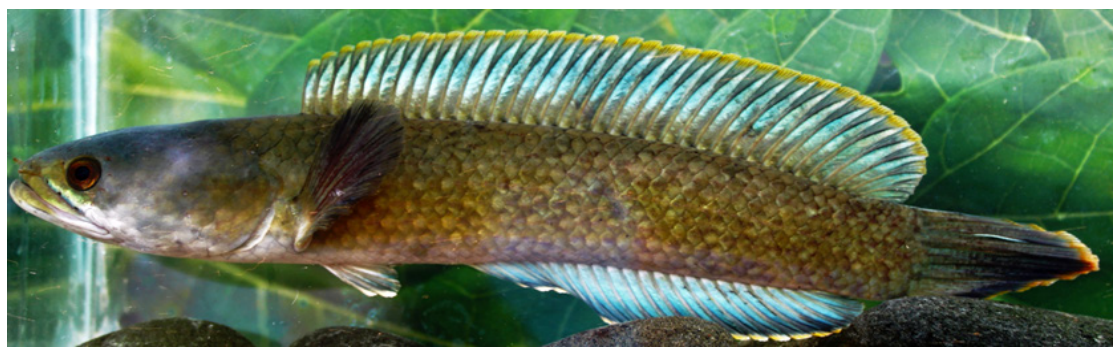

(a)

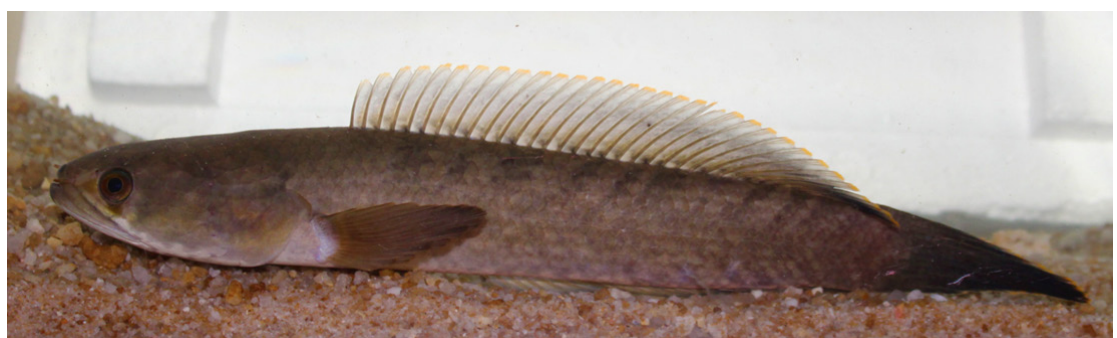

(b)

Fig. 3. Channa royi sp. nov. (a) Adult, $190.5 \mathrm{~mm} \mathrm{SL}$, showing black pectoral fin, uncatalogued, (b) Adult, $165.1 \mathrm{~mm}$, showing pale grey pectoral fin, uncatalogued. (both maintained in aquarium) (Photo credits: J. Praveenraj) 
name 'Andaman emerald snakehead' is given considering its unique greenish dorsum.

Distribution: Channa royi sp. nov. is currently known only from South, Middle and North Andaman Islands, India and is abundant in ditches, ponds and hill streams of the sampled locations. The holotype was collected from clear, slow flowing water with cobble substrate without much aquatic vegetation.

Genetic analysis: All partial COX1 sequences derived were submitted in the National Center for Biotechnology Information (NCBI) GenBank database with accession numbers: Channa royi - KY214136-KY214138, KY214142, KY562574-KY562578 and KY863527KY863530; Channa limbata, topotype $=\mathrm{KY} 563772$ and Channa gachua, topotype - KY214140-KY214143. Additional DNA sequences for the phylogenetic trees were retrieved from the NCBI Channidae barcode library generated by Conte-Grand et al. (2017) (Table 2)

Model test suggested the best fit nucleotide substitution model to be the Tamura Nei model (TN93) with gamma distribution and assumption that a certain fraction of sites are evolutionarily invariable $(+I)[(G+I), \mathrm{AICc}=11301.56274, \ln L=-5544.373986$, $(+I)=0.569402471, \quad(+G)=1.790251869]$. The maximum likelihood tree generated, suggests that, the closest genetic congener of $C$. royi is $C$. harcourtbutleri (Fig. 5) (MF496804-MF496808), from which it differs by genetic distance (K2-P distance) of 2.4-2.8\%. Though C. royi belongs to the $C$. gachua species-group, it differs from topotypic C. gachua (KY214140, KY214143) from Bengal by a genetic distance of 20.7-22.8\%. Genetic distance between the new species and members of the C. gachua species-group and other congeners are provided in the Table 3.

\section{Discussion}

Based on the results of molecular analyses by $\mathrm{Li}$ et al. (2005), Britz (2008) proposed the Channa gachua species-group. All species under this group have their pectoral fins with varying number of dark and light semicircular bands. In addition to C. orientalis, C. gachua, C. burmanica, C. bleheri and C. barca, Britz (2008) included C. stewartii, C. aurantimaculata, C. ornatipinnis and $C$. pulchra also to the C. gachua species-group. Other recently described species, i.e., C. melanostigma, C. andrao, C. pardalis, C. aurantipectoralis, C. pomanensis, C. stiktos, C. quinquefasciata and C. bipuli also belong to the C. gachua species-group. Channa royi unquestionably belongs to this group of species as its pectoral fins have the characteristic semicircular bands and two large cycloid scales on each side of lower jaw. In the present work, these characters are strongly supported by the phylogenetic analysis, depicting three major clades separating C. gachua, C. marulius and Parachanna groups. Channa royi sp. nov. shares close relatedness with $C$. harcourtbutleri (Annandale, 1918), forming a sister clade in the phylogenetic tree. It shares similar morphometry in most aspects but, differs in having a greater inter-orbital width 26.5-34.1\% (vs. 25.9-26.5\% HL) of C. harcourtbutleri. C. royi sp. nov. further differs from $C$. harcourtbutleri in having pelvic fin rays 5 (vs. 5-7, mode 6); branched caudal rays, i-ii, 12-13, i-ii ( $v s$. ii, 15, ii); pre-dorsal scales from base of first dorsal ray to the first fused cephalic scales 6-7 (vs. 4); lateral line scales, dropping one scale row at scale 12-13 (vs. 15-6); pectoral fin pale brown to black with 2-3 inconspicuous pale grey to black semicircular bands ( $v s$. pectoral fins greyish, with 2-5 semi-concentric black rings); dorsum greenish-grey (vs. black to purplish-black); dropping one scale row 12-13 (vs. 15-16) and dorsal fin bluish-green, anal fin bright-blue ( $v s$. dorsal and anal fins purplish-black to dark-grey); throat region marbled with whitish blotches on grey background (vs. throat marbled with bluish spots and blotches on dark-grey background).

Though $C$. royi sp. nov. forms part of the C. gachua species-group, it can be distinguished from topotypic C. gachua (Hamilton, 1822) by the presence (vs. absence) of large canine like teeth on the palatine (Fig. 4 b, k); 43 (vs. 42) vertebrae; 42-45 + 1-3 (vs. 39-40 +1 ) lateral line scales and absence ( $v s$. presence) of an ocellus at the posterior rays of the dorsal fin in juvenile fish (Fig. 2 d). The adults of C. gachua can be easily distinguished from $C$. royi by its bulged cheek and head appearing more convex when viewed laterally (Fig. 2c), whereas $C$. royi sp. nov. possess a uniform cheek and head with flat ventral profile.

C. royi sp. nov. can be readily distinguished from both $C$. stewartii (Playfair, 1867) and C. melanostigma Geetakumari and Vishwanath, 2011 by the absence (vs. presence) of numerous black spots along the side of the body; $6 \frac{1}{2}\left(\right.$ (vs. $\left.71 \frac{1}{2}\right)$ scales below lateral line at anal fin origin; 43 (vs. 48 and 50) vertebrae respectively; a more slender ( $v s$. deeper) fifth ceratobranchial (Fig. 4 d, g) and the absence (vs. presence) of large canine like teeth on the anterior fourth of the lower jaw (Fig. 4C, F, I). Channa royi can further be distinguished from C. stewartii by the presence of 34-38 (vs. 39-40) dorsal fin rays and $4246+1-3$ (vs. 47-48 +2 ) lateral-line scales. It can be distinguished from $C$. melanostigma by the absence (vs. presence) of 14-15 distinct zigzag cross bars on the caudal fin. Further, C. royi sp. nov. can be distinguished 
Table 2. GenBank accession numbers from NCBI, locations and voucher numbers for COI gene sequences of various species of Channa

\begin{tabular}{|c|c|c|c|}
\hline Species & Location & Voucher & GenBank Accession No. \\
\hline Channa andrao & India & - & MF496661 \\
\hline Channa aurantimaculata & India & CA1001 & KJ847157 \\
\hline Channa aurantipectoralis & Mizoram, India & - & MH559819 \\
\hline Channa barca & - & - & MF496699 \\
\hline Channa bipuli & Garbhanga, Assam, India & ZSI FF 7650 & MG825616 \\
\hline Channa bleheri & Alipurduar, India & - & MF496702 \\
\hline Channa burmanica & Putao, Myanmar & - & MF496706 \\
\hline Channa gachua & Java, Bogor, Indonesia & & MF496735 \\
\hline Channa gachua & Seletar, Singapore & & MF496730 \\
\hline Channa gachua & Bagayat, Maharashtra, Western India & CIARI/FF-50 & KY863544 \\
\hline Channa gachua & Ponneri, Tamil Nadu, South India & CIARI/FF-51 & MG989241 \\
\hline Channa gachua & Indonesia & - & MF496767 \\
\hline Channa gachua & Laos & - & MF496766 \\
\hline Channa gachua (Topotype) & Ganrapota, North 24 Parganas, West Bengal, India & CIARI/FF-25 & KY214140 \\
\hline Channa gachua (Topotype) & Ganrapota, North 24 Parganas, West Bengal, India & CIARI/FF-27 & KY214143 \\
\hline Channa harcourtbutleri & - & - & MF496809 \\
\hline Channa harcourtbutleri & $\begin{array}{l}\text { Inn Khaung-Chaung between Aung Ban and } \\
\text { Heho Chaung, Myanmar }\end{array}$ & - & MF496804 \\
\hline Channa harcourtbutleri & - & - & MF496805 \\
\hline Channa harcourtbutleri & & & MF496806 \\
\hline Channa harcourtbutleri & & & MF496807 \\
\hline Channa harcourtbutleri & & & MF496808 \\
\hline Channa limbata & West Java, Bogor, Indonesia, & CIARI/FF-34 & KY563772 \\
\hline Channa lucius & Ketapang fish market, Borneo, Indonesia & - & MF496832 \\
\hline Channa marulius & $\begin{array}{l}\text { Bengalen aquarium trade, India; } \\
\text { Aquarium Glaser, Frankfurt, Germany }\end{array}$ & & MF496849 \\
\hline Channa ornatipinnis & - & - & MF496874 \\
\hline Channa pardalis & - & - & MF496879 \\
\hline Channa pseudomarulius & Kerala aquarium trade, India & - & MF496884 \\
\hline Channa pulchra & - & - & MF496885 \\
\hline Channa punctata & Golbazar, India, & WILD-17-PIS-330 & MF462273 \\
\hline Channa quinquefasciata & $\begin{array}{l}\text { Torsa River, Howlong bridge, near Bhutan foothills, } \\
\text { North Bengal, India }\end{array}$ & ZSI FF 7906 & MH627036 \\
\hline Channa royi & Goalghar ditch, South Andaman, India & CIARI/FF-10 & KY214142 \\
\hline Channa royi & Goalghar ditch, South Andaman, India & CIARI/FF-11 & KY214136 \\
\hline Channa royi & Garacharama stream, South Andaman, India & CIARI/FF-13 & KY214138 \\
\hline Channa royi & Garacharama stream, South Andaman, India & CIARI/FF-14 & KY562577 \\
\hline Channa royi & Garacharama stream, South Andaman, India & CIARI/FF-15 & KY562578 \\
\hline Channa royi & Diglipur, North Andaman, India & CIARI/FF-17 & KY863530 \\
\hline Channa royi & Diglipur, North Andaman, India & CIARI/FF-18 & KY863529 \\
\hline Channa royi & Nimbudera, Middle Andaman, India & CIARI/FF-19 & KY863528 \\
\hline Channa royi & Nimbudera, Middle Andaman, India & CIARI/FF-20 & KY863527 \\
\hline Channa royi & Mannarghat, South Andaman, India & CIARI/FF-21 & KY214137 \\
\hline Channa royi & Mannarghat, South Andaman, India & CIARI/FF-22 & KY562575 \\
\hline Channa royi & Mannarghat, South Andaman, India & CIARI/FF-23 & KY562574 \\
\hline Channa royi & Mannarghat, South Andaman, India & CIARI/FF-24 & KY562576 \\
\hline Channa stewartii & - & - & MF496931 \\
\hline Channa stiktos & Mizoram, India, & - & MH559824 \\
\hline Channa striata & $\begin{array}{l}\text { Aquarium trade, Guahati, Assam, India, } \\
\text { Aquarium Glaser, Frankfurt, Germany }\end{array}$ & & MF496935 \\
\hline Parachanna africana & - & - & MF496973 \\
\hline
\end{tabular}

'-' Denotes lack of data 
Table 3. K2-P genetic distance (\%) between Channa royi sp. nov. and its congeners

\begin{tabular}{ll}
\hline Species & Channa royi sp. nov. \\
Channa harcourtbutleri & $2.4-2.8$ \\
Channa gachua (Laos) & $5.8-6.3$ \\
Channa gachua (Indonesia) & $5.6-6.0$ \\
Channa limbata & $5.8-6.3$ \\
Channa gachua (Java Bogor) & $5.8-6.2$ \\
Channa gachua (Singapore Seletor) & $5.8-6.5$ \\
Channa andrao & $17.8-18.8$ \\
Channa aurantimaculata & $14-14.8$ \\
Channa barca & $18.7-19.9$ \\
Channa pardalis & $17.7-18.4$ \\
Channa bipuli & $15.2-15.7$ \\
Channa bleheri & $18.4-18.7$ \\
Channa stewartii & $16.5-17.4$ \\
Channa quinquefasciata & $13.2-13.9$ \\
Channa burmanica & $18.1-18.7$ \\
Channa aurantipectoralis & $20.2-21.2$ \\
Channa gachua (Western India) & $19.2-20.2$ \\
Channa orientalis & $21.2-21.9$ \\
Channa gachua (South India) & $19.5-20.8$ \\
Channa gachua (Topotype) & $20.7-22.8$ \\
Channa pulchra & $27-28.2$ \\
Channa stiktos & $26.6-27.7$ \\
Channa ornatipinnis & $27.6-28$ \\
Channa punctata & $26.8-28$ \\
Channa striata & $25.4-26.9$ \\
Channa panaw & $28.1-28.9$ \\
Channa lucius & $33.4-34.3$ \\
Channa pseudomarulius & $28.3-29.9$ \\
Channa marulius & $31.2-32.6$ \\
Parachanna africana (outgroup) & $33.5-34.3$ \\
& \\
&
\end{tabular}

from C. aurantimaculata Musikasinthorn 2000 and C. barca (Hamilton, 1822) by its fewer dorsal-fin rays 34-38 (vs. 45-52) and fewer lateral line scales 42-45 + 1-3 (vs.> 50).

C. royi sp. nov. differs from $C$. orientalis Bloch \& Schneider, 1801, C. burmanica Chaudhuri 1919, C. bleheri Vierke 1991 and C. andrao Britz 2013, due to the presence (vs. absence) of pelvic fins. It can be distinguished from both C. ornatipinnis Britz 2008 and C. pulchra Britz 2008 , by the absence ( $v s$. presence) of spots on the postorbital region and flanks, 61/2 (vs. 71/2) scales below lateral line at anal fin origin; absence ( $v s$. presence) of black blotches on the anterior third of the dorsal fin and absence (vs. presence) of parallel, oblique, linear white marks at anal fin base.

Six species viz., Channa pardalis Knight, 2016, C. aurantipectoralis Lalhlimpuia et al., 2016, C. pomanensis Gurumayum and Tamang, 2016 and C. stiktos

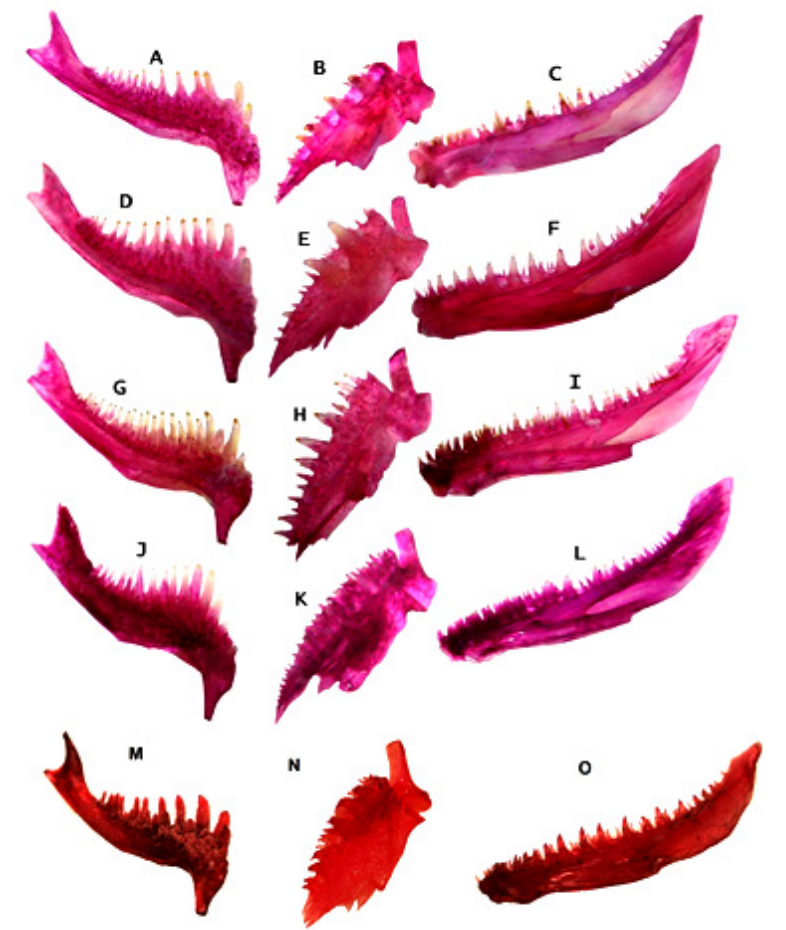

Fig. 4. Left side bones of Channa species: row 1- C. royi; row 2 - C. stewartii; row 3 - C. melanostigma; row 4 - C. gachua; row 5 - C. limbata. Column 1 - fifth ceratobranchial; column 2 - palatine; column 3 - inner view of dentary. (Photo credits: Dr. J. D. M. Knight and Dr. J. Praveenraj)

Lalramliana et al., 2018, C. quinquefasciata Praveenraj et al., 2018a and C. bipuli Praveenraj et al., 2018b have been described recently from north-eastern India. Channa royi sp. nov. can be distinguished from C. pardalis and C. bipuli by the absence (vs. presence) of numerous large black spots on the post-orbital region of the head, opercle and body; transverse scale $3 \frac{1}{2}$ (vs. 41/2) above lateral line and 43 (vs. 45) vertebrae. It can be distinguished from $C$. aurantipectoralis, by presence od fewer lateral line scales (42-45 vs. 51-64); 14-15 pectoral fin rays (vs. 13-14); pectoral fin pale brown to black with 2-3 semicircular bands ( $v s$. orange pectoral fin devoid of any bands) and transverse scale rows $3 \frac{1}{2} / 1 / 61 / 2$ (vs. 51/2-61/2/1/ 71/2-81/2). Channa royi $\mathrm{sp}$. nov. differs from Channa pomanensis in having fewer rows of transverse scales $\left(3^{1 / 2} / 1 / 6^{1 / 2}\right.$ vs. $\left.4 \frac{1}{2}-5 \frac{1}{2} / 1 / 71 / 2-81 / 2\right)$, fewer caudal fin rays (i-ii, 10-12, i-ii vs. i-ii, 11-14, ii-iii) and varies in colouration of outer margin of dorsal and anal fin with thin orange border (vs. white margin). Channa royi $\mathrm{sp}$. nov. also differs from $C$. quinquefasciata by the absence of stripes on the body ( $v s$. presence of five stripes), shorter snout length (17.7-23.5 vs.18.2-26.0\% HL) and more circumpeduncular scales (12-13 vs. 9-10). 


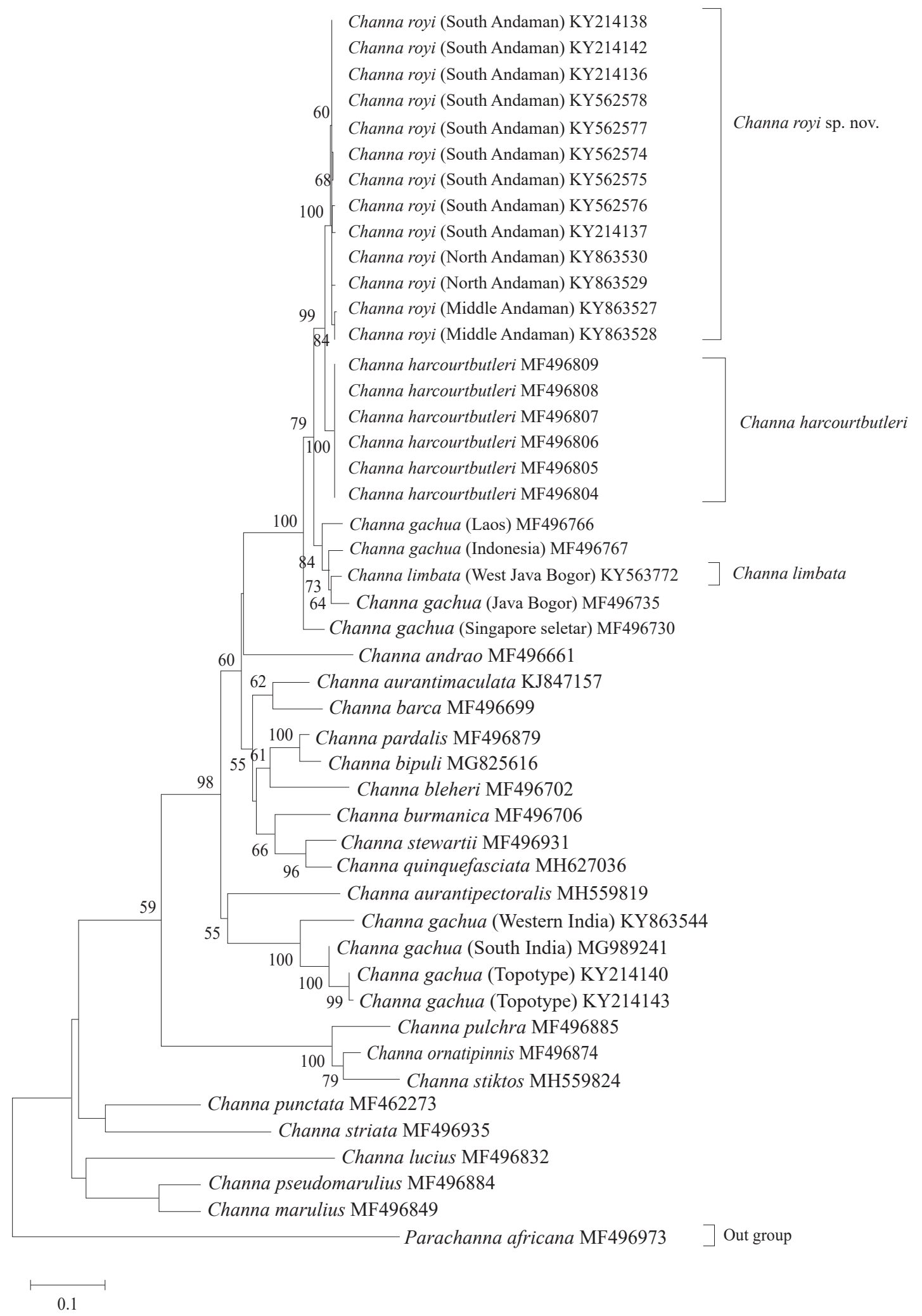

Fig. 5. Phylogenetic position of Channa royi sp. nov. based on maximum likelihood analysis (Values along the nodes are percent bootstraps for 1000 iterations; Parachanna africana is used as out-group) 
It is relevant to note that quite a few descriptions were synonymised with C. gachua. Of these Ophiocephalus aurantiacus, Hamilton 1822 (type locality: Goyalpara on the north-east frontier of Bengal), Ophicephalus marginatus, Cuvier, 1829 (type locality: Vizagapattam, Kottelat, 2000) and O. fuscus Cuvier, 1831 (type locality: Bengal/Maissour) have been reported from India. We were able to examine specimens collected from North-east India, West Bengal, Visakhapatnam (=Vizagapattam) and the River Cauvery, which flows through Mysore (=Maissour). In case of O. fuscus, photograph of the syntype (MNHN A.398, A.623) was examined. C. royi sp. nov. can be distinguished using specimen photographs and the topotypes, which were similar to C. gachua in having more than (vs. less than) 42 lateral line pored scales. $C$. royi sp. nov. can be easily distinguished from its topotypes by the difference in pectoral fins which are pale brown to black with 2-3 pale grey to black inconspicuous semicircular bands (vs. pectoral fin orange with 4-5 semicircular, narrow black bands) and absence (vs. presence) of an ocellus at the posterior rays of the dorsal fin in juvenile fish in specimens from West Bengal, Visakhapatnam and the River Cauvery.

Ophicephalus limbatus Cuvier, 1831 (type locality: Bogor, West Java, Indonesia, see Kottelat, 2000) is shown only on a figure (Cuvier and Valenciennes, 1831: pl. 201) based on a specimen from Java. Kottelat (2000) concluded that the MNHN A.396 [115 mm SL, $142 \mathrm{~mm} \mathrm{TL}]$ is the model of the plate 201 figured by Cuvier, in Cuvier and Valenciennes, 1831 for O. limbatus (=C. limbata). Photographs of MNHN A.396 were examined, which is clearly differentiated from Channa royi $\mathrm{sp}$. nov. in possessing a uniform, depressed head and body; equal head depth and body depth; mid row pored scale 10 (vs.12-13); pre-dorsal scales from base of first dorsal ray (scale on which it is attached, not counted) to first fused cephalic scale 8 (vs. 61/2-7 in C. royi sp. nov.). In addition, from the photograph it is very evident that the MNHN A.396 specimen has a series of canine-like teeth in the lower jaw, which is absent in C. royi sp. nov. Topotypes representing $C$. limbata (Fig. 6 a,b) from Bogor, West Java, Indonesia matched the scale count, teeth pattern and general appearance of the holotype (MNHN A.396). Channa royi sp. nov. differs from the topotypic C. limbata in possessing more lateral line pored scales $(>40) v s$. 39-40 and total vertebrate 43 (vs. 42). Further, the topotypic Channa limbata can be distinguished from C. royi sp. nov. by its teeth pattern, it has two rows of teeth on the lower jaw with an outer row of long, slender, pointed canine teeth in the anterior fourth ceratobranchial ( $v s$. presence of small minute numerous needle like teeth);

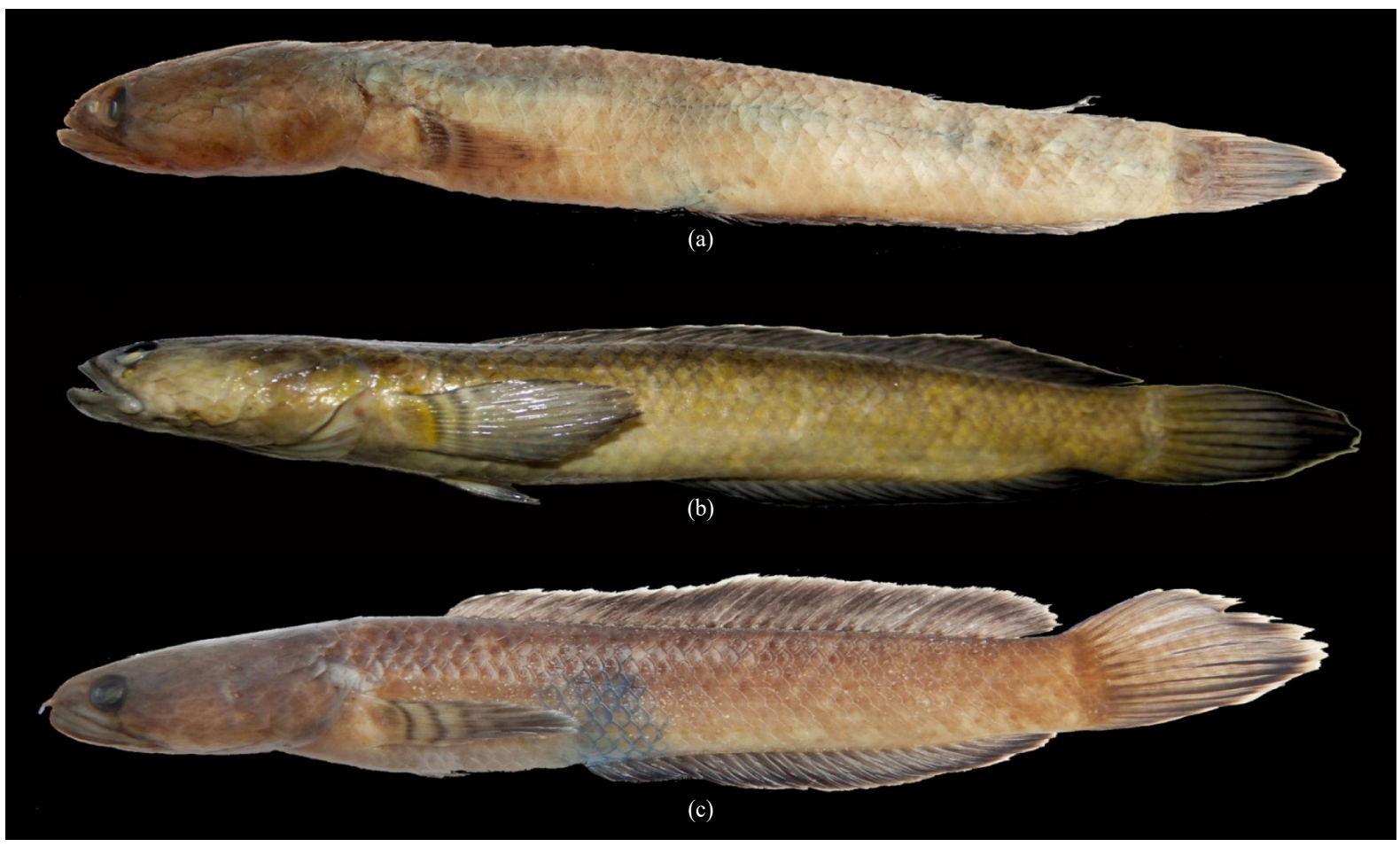

Fig. 6. (a). Channa limbata topotype, West Java, Bogor, Indonesia, CIARI/FF-36, 112.0 mm, (b). Channa limbata topotype, West Java, Bogor, Indonesia $141.67 \mathrm{~mm}$ SL, (c). Channa sp. from Ciliwung River, West Java, Indonesia, CIARI/FF-33, $117.12 \mathrm{~mm} \mathrm{SL}$ (Photo credit: Dr. J. Praveenraj) 
9-10 large canine teeth in the anterior fourth of the lower jaw (vs. absent in C. royi sp. nov.); 13 (vs. 7) blunt inward facing teeth in the fifth ceratobranchial; palatine with 2 rows of teeth and 7-8 (vs. 4-6) canine-like teeth (Fig 4. m, n, o). Morphologically C. royi sp. nov. differs from the topotypic $C$. limbata by possessing a longer head length (27.5-34.1 vs. 24.3-25.7\% SL); greater body depth (13.0-18.5 vs. 10.54-12.34\% SL). Channa royi $\mathrm{sp.}$ nov. varies from the topotypic $C$. limbata sequence (KY563772) by a pair-wise sequence distance of 5.8-6.3\%. Phylogenetic analysis also grouped the topotypic Channa limbata sequence (KY563772) with other GenBank sequence, C. gachua from Bogor, Java (MF496735), Indonesia (MF496767), Java, Bogor (MF496730) under a single clade, which indicates distinctiveness of the Indonesian Channa clade including C. limbata (Conte-Grand et al., 2017).

Two other names, Philypnoides surakartensis Bleeker, 1849 and Ophiocephalus apus Canestrini, 1861, which are two Indonesian species and synonymous to C. gachua (Kottelat, 2013) also represent C. limbata group (Conte-Grand et al., 2017). We have also examined specimens from Indonesia and nearby localities (Fig. 6C) and the photograph of Ophiocephalus apus lectotype (MCSNG 39373) and found that Channa royi sp. nov. differs from the lectotype (MCSNG 39373) by possessing 12-13 (vs. 8) mid row pored scales; presence ( $v s$. absence) of pelvic fin. Channa royi sp. nov. differs from the fresh specimens by 42-45 (vs. 29-34) lateral line pored scales; pectoral fin pale brown to black with 2-3 pale grey to black inconspicuous semicircular bands ( $v s$. pectoral fin radiating from pale orange to bright orange with 2-4 broad semicircular bands).

Ophicephalus montanus M'Clelland and Griffith 1842 (type locality: Afghanistan ?), s currently a synonym of C. gachua (Kottelat, 2013). Channa royi sp. nov. can be distinguished from $O$. montanus by presence of 34-38 (vs. 32) dorsal fin rays and 22-25 (vs. 17) anal fin rays.

Another synonym of C. gachua is Ophiocephalus gachua var. basalis Gunther, 1861 (type locality: East Indies). It is most probably C. gachua (Kottelat, 2013), as Gunther mentions that this species has a black ocellus edged with white on the hindmost part of the dorsal fin when young, which is absent in C. royi sp. nov.

Ophiocephalus guachua var. malaccensis Peters, 1868 (type locality: Singapore), which was previously considered the synonym of $C$. gachua and now represent the population of eastern lineage for which the oldest name was $C$. limbata (Conte-Grand et al., 2017). Channa royi sp. nov.can be distinguished from this species by its 34-38 (vs. 34) dorsal-fin rays, and by the presence (vs. absence) of large canine teeth in the palatine. We have also examined photographs and meristic data of Channa sp. from Singapore which are distinct from C. royi sp. nov. by its pectoral fin possessing 4 black semicircular bands with orange interspaces ( $v s$. pale brown to black with 2-3 pale grey to black inconspicuous bands), mid row pored scales 11 (vs. 12-13) and transverse scales $3 \frac{1}{2} / 1 / 71 / 2$ (vs. $3^{1 / 2} / 1 / 61 / 2$ ). Channa royi $\mathrm{sp}$. nov. genetically differs from C. gachua from Singapore (MF496730) reported by Conte-Grand et al. (2017) by a pair-wise sequence distance of $5.8-6.5 \%$.

Channa longistomata Nguyen, Nguyen and Nguyen, 2012, a recently described Channa species from Vietnam is tentatively considered as a synonym of C. gachua (Kottelat, 2013) probably because the original description in Vietnamese does not clearly differentiate the species from C. gachua. The image of C. longistomata in Nguyen et al. (2012) (159, Fig. 1) shows a species with a short rounded head and light coloured pectoral fins with three to five dark semicircular bands. Channa royi sp. nov. can be distinguished from $C$. longistomata in having pale brown to black pectoral fin with 2-3 pale grey to black inconspicuous bands.

\section{Comparative materials}

Channa harcourtbutleri: ZSI F9439/1, 1 ex., holotype, 46.8 mm SL; Myanmar: southern Shan State, Inle Lake; ZSI F9451 /1, 2 ex., 39.1-53.0 mm SL; Myanmar: southern Shan State, Thumakam (Hsamongkam); N. Annandale; Additional data from $\mathrm{Ng}$ et al. (1999).

Channa gachua: CIARI/FF-25-27, 3 ex., 95.1-94.3 mm SL (95.1 and 95.2 mm SL, GenBank Acc. No. KY214140, KY214143), Ganrapota, North 24 Parganas, West Bengal, India, October 2016, Soutrik Gosh; ZSI FF 7654, 2 ex., 34.2-67.0 mm SL $(67.0 \mathrm{~mm}$ SL, GenBank Acc. No. MG989241), Arani River, Pazhaverkadu, Tamil Nadu; CIARI/FF-46, $109.0 \mathrm{~mm}$ SL, Cauvery River, Erode, Salem District, Tamil Nadu; CIARI/FF-48, $112.0 \mathrm{~mm}$ SL, Dhahagoan, Dhapoli District, Maharashtra; CIARI/ FF-51, 1 ex., 109.4 mm SL, Ponneri, Tiruvallur District, Southern India, J. Praveenraj and team; MKC191, 11 ex., 46.2-98.2 mm SL, Ganrapota, North 24 Parganas, West Bengal, India, March 2009, Andrew Rao (Two specimens 78.9 and $90.9 \mathrm{~mm}$ SL were cleared and stained for osteology); MKC 182, 1 ex., $52.1 \mathrm{~mm}$ SL, Meghalaya, India, March 2009, A. Rao. MKC 430, 1 ex., 49.7 mm SL, Kaveripattanam, Tamil Nadu, India, July 2015, Nikhil Sood; MKC 431, 6 ex., 56.3-97.9 mm SL, Visakhapatnam, India, July 2015, Pranay Kumar. 
Channa limbata: CIARI/FF-28-33, 6 ex., 86.9-117.1 mm SL, Ciliwung River, West Java, Indonesia (6³9'32.9"S 106 $\left.53^{\prime} 01.0^{\prime \prime E}\right)$, August 2014, Beni Halalludin; CIARI/ FF-34-37, 4 ex., 78.0-121.0 mm SL, Bogor, West Java, Indonesia $\left(6^{\circ} 32^{\prime} 35.8^{\prime \prime S} \quad 106^{\circ} 49^{\prime} 23.0^{\prime \prime} \mathrm{E}\right)$, September 2014, Silukoki Thariq (78.0 mm SL, GenBank Acc. No. KY563772) (two specimens 121.0 and $101.0 \mathrm{~mm} \mathrm{SL}$, were cleared and stained for osteology); CIARI/FF-52-53, 2 ex., 120.7-141.7 mm SL, Bogor, West Java, Indonesia, (6³2'35.8"S 106²9'23.0"E), January 2014, Heiko Bleher.

Channa stewartii: CIARI/FF-38, 1 ex., 118.5 mm SL, Jaigaon, Jalpaiguri District, West Bengal, April 2015, Soutrik Gosh; MKC 100.0, 2 ex., 109.2-128.6 mm SL, Cachar, near Meghalaya border, Assam December 2010, A. Rao (128.6 mm SL, specimen was cleared and stained for osteology); MKC 192, 5 ex., 78.1-121.2 mm SL, Jaigaon, Jalpaiguri District, West Bengal, March 2009, Andrew Rao (121.2 mm SL, specimen was cleared and stained for osteology).

Channa melanostigma: MKC 012, 4 ex., 66.2-122.9 mm SL, Brahmaputra River, Tinsukia, Assam, November 2008, Andrew Rao (two specimens 120.2 and $122.9 \mathrm{~mm}$ SL, were cleared and stained for osteology).

Channa pardalis: ZSI/FF 7652, 123.7 mm SL; CIARI/FF43, 114.5 mm SL (GenBank Acc. No. MG825618), West Khasi Hills, Meghalaya, India.

Photographs examined

Ophicephalus limbata: holotype-MNHN A.396

Ophicephalus fuscus: syntypes-MNHN A.398, A. 623

Ophiocephalus apus lectotype: MCSNG 39373

Channa sp. from Singapore provided by Hung Tsun Cheng"

\section{Acknowledgements}

Authors gratefully acknowledge the grants offered by ICAR through the project on 'Consortia Research Platform on Agro-biodiversity'. We are grateful to Dr. Keith Philip, MNHN and Dr. Giuliano Doria, MCSNG for providing the requested museum images. We also appreciate the effort taken by Dr. Subhrendu Sekhar Mishra, ZSI, Kolkatta and Shri P.T. Rajan, ZSI, Port Blair for providing the specimen details. We thank and appreciate the help rendered by Silukoki Thariq, fish exporter, West Java and Shri Roy, Mya Thein exporters, Myanmar for providing the specimens. We sincerely thank Dr. K. Shakthivel and Shri Manigundan, ICAR-CIARI for their support in DNA studies. We thank Andrew Rao, Dr. Rajeev Kumar Jha, Pranay Kumar, Abhijeet Sahsane, Rahul Vijay Kolekar, Deepak Dhayalkar, Mrugendra Khot and Omkar for providing us the comparative material and information used in this study. Data and photographs offered by Hung Tsung Cheng, Singapore is greatly appreciated. The second author acknowledges the permit No. FSD/Imp. Comm. /2015/12 dt. 05.05.2015 granted by the ICARCIARI, Port Blair, for collection and transportation of specimens. The support and assistance of Saffic, Karlus and Javed during the field trips are also acknowledged.

\section{References}

Adamson, E. A. and Britz, R. 2018. The snakehead fish Channa aurolineata is a valid species (Teleostei: Channidae) distinct from Channa marulius. Zootaxa, 4514(4): 542-552. DOI: http://dx.doi.org/10.11646/zootaxa.4514.4.7

Altschul, S. F., Gish, W., Miller, W., Myers, E. W. and Lipman, D. J. 1990. Basic local alignment search tool, J. Mol. Biol., 215(3): 403-410.

Bleeker, P. 1849. Bijdrage tot de kennis der Blennioïden en Gobioiden van den Soenda-Molukschen archipel, met beschrijving van 42 nieuwe species. Verhandelingen van het Bataviaasch Genootschap van Kunsten en Wetenschappen, 22(6): 1-40.

Britz, R. 2008. Channa ornatipinnis and C. pulchra, two new species of dwarf snakeheads from Myanmar (Teleostei: Channidae). Ichthyol. Explor. Freshwat., 8: 335-344.

Britz, R. 2013. Channa andrao, a new species of dwarf snakehead from West Bengal, India (Teleostei: Channidae). Zootaxa., 3731(2): 287-294. DOI: http://dx.doi.org/10.11646/zootaxa. 3731.2.9.

Britz Canestrini, G. 1861. Sopra una nuova specie di Ophicephalus senza ventrali Ophicephalus apus. Archivio per la Zoologia, l'Anatomia e la Fisiologia, 1: 77-79, pl. 4.

Conte-Grand, C., Britz, R., Dahanukar, N., Raghavan, R., Pethiyagoda, R., Tan, H. H., Hadiaty, R. K., Yaakob, N. S. and Ruber, L. 2017. Barcoding snakeheads (Teleostei, Channidae) revisited: Discovering greater species diversity and resolving perpetuated taxonomic confusions. PloS ONE, 12.9: e0184017. https://doi.org/10.1371/journal. pone. 0184017 .

Courtenay, W. R. and Williams, J. D. 2004. Snakeheads (Pisces, Channidae) - a biological synopsis and risk assessment. U. S. Geological Survey Circular, U.S. Department of the Interior, Washington DC, USA, 143 pp.

Cuvier, G. 1829. Le regne animal distribue d'apres son organisation, pour servir de base a l'histoire naturelle des animaux et d'introduction a l'anatomie comparee, Deterville, Paris 2: xv $+406 \mathrm{pp}$.

Cuvier, G. and Valenciennes, A. 1831. Histoire naturelle des poissons. Tome septième. Levrault, Paris xxix +531 pp., pls. 170-208. 
Edgar, R. C. 2004. MUSCLE: multiple sequence alignment with high accuracy and high throughput. Nucleic Acids Res., 32: 1792-1797. doi: 10.1093/nar/gkh340.

Fricke, R., Eschmeyer, W. and Fong, J. F. 2018. Species by family/subfamily in the Catalog of Fishes. http://research archive.calacademy.org/research/ichthyology/catalog/ SpeciesBy Family.asp.

Geetakumari, K. and Vishwanath, W. 2011. Channa melanostigma, a new species of freshwater snakehead from north-east India (Teleostei: Channidae). J. Bombay Nat. Hist. Soc., 107: 231-235.

Gurumayum, S. D. and Tamang, L. 2016. Channa pomanensis, a new species of snakehead (Teleostei: Channidae) from Arunachal Pradesh, north-eastern India. Species, 17(57): 175-186.

Gunther, A. 1861. Catalogue of the acanthopterygian fishes in the collection of the British Museum, vol. 3. British Museum, London $\mathrm{xxv}^{+}, 586 \mathrm{pp}$.

Hamilton, F. 1822. An account of the fishes of River Ganges and its branches. George Ramsay and Co., London, 405 pp.

Kimura, M. 1980. A simple method for estimating evolutionary rate of base substitutions through comparative studies of nucleotide sequences. J. Mol. Evol., 16: 111-120. doi. org/10.1007/BF01731581.

Koressaar, T. and Remm, M. 2007. Enhancements and modifications of primer design program Primer 3. Bioinformatics, 23(10): 1289-1291.

Kottelat, M. 2000. Nomenclature and types of Ophicephalus marginatus and $O$. limbatus (Teleostei: Channidae). J. South Asian Nat. Hist., 5(1): 95-96.

Kottelat, M. 2013. The fishes of the inland waters of Southeast Asia: A catalogue and core bibliography of the fishes known to occur in freshwaters, mangroves and estuaries. Raffles Bull. Zool., 27 (Supplement): 1-663.

Kumar, S., Stecher, G. and Tamura, K. 2016. MEGA7: Molecular Evolutionary Genetics Analysis version 7.0 for bigger datasets. Mol. Biol. Evol., 33(7): 1870-1874.

Knight, J. D. M. 2016. Channa pardalis, a new species of snakehead (Teleostei: Channidae) from Meghalaya, northeastern India. J. Threat. Taxa, 8(3): 8583-8589. http:// dx.doi.org/10.11609/jott.2168.8.3.8583-8589.

Lakra, W. S., Goswami, M., Gopalakrishnan, A., Singh, D. P., Singh, A. and Nagpure, N. S. 2010. Genetic relatedness among fish species of genus Channa using mitochondrial DNA genes. Biochem. Syst. Ecol., 38: 1212-1219. DOI: 10. 1016/j.bse.2010.12.012.

Lalhlimpui, D. V., Lalronung, S. and Lalramliana 2016. Channa aurantipectoralis, a new species of snakehead from Mizoram, north-eastern India (Teleostei: Channidae). Zootaxa, 4147(3): 343-350. doi: 10.11646/ zootaxa.4147.3.7.
Lalramliana, Knight, J. D. M., Lalhlimpuia, D. V. and Singh, M. 2018. Integrative taxonomy reveals a new species of snakehead fish, Channa stiktos (Teleostei: Channidae), from Mizoram, North-eastern India. Vert. Zool., 68(2): 165-175.

Lee, P. G. and Ng, P. K. L. 1994. The systematics and ecology of snakeheads (Pisces: Channidae) in Peninsular Malaysia and Singapore. Ecology and conservation of South-east Asian marine and freshwater environments including wetlands, Springer, Dordrecht, p. 59-74.

Li, X., Musikasinthorn, P. and Kumazawa, Y. 2005. Molecular phylogenetic analysis of snakeheads (Perciformes: Channidae) using mitochondrial DNA sequences. Ichthyol. Res., 53: 148-159.

M'Clelland, J. 1842. On the freshwater fishes collected by William Griffith during his travels from 1835 to 1842 . Calcutta J. Nat. Hist., Miscellaneous Arts and Sciences in India, 2(8): 560-589, pls. 6, 15, 18 and 21.

Murray, A. M. 2012. Relationships and biogeography of the fossil and living African snakehead fishes (Percomorpha, Channidae, Parachanna). J. Vertebr. Paleontol., 32 (4): 820-835. https://doi.org/10.1080/02724634.2012.664595.

Musikasinthorn, P. 1998. Channa panaw, a new Channid fish from the Irrawaddy and Sittang basins, Myanmar. Ichthyol. Res., 45 (4): 355-362.https://doi.org/10.1007/BF02725188.

Musikasinthorn, P. 2000. Channa aurantimaculata, a new channid fish from Assam (Brahmaputra River basin), India, with designation of a neotype for C. amphibeus (McClelland, 1845). Ichthyol. Res., 47: 27-37. http:// dx.doi.org/10.1007/bf02674310.

Nei, M. and Kumar, S. 2000. Molecular evolution and phylogenetics. Oxford University Press, New York, 333 pp.

Ng, P. K. L. and Lim, K. K. P. 1990. Snakeheads (Pisces: Channidae): Natural history, biology and economic importance. In: Chou, L. M. and Ng, P. K. L. (Eds.), Essays in zoology. Department of Zoology, National University of Singapore, p. 127-152.

Ng, H. H., Ng, P. K. L. and Britz, R. 1999. Channa harcourtbutleri (Annandale, 1918): a valid species of snakehead (Perciformes: Channidae) from Myanmar. J. South Asian Nat. Hist., 4(1): 57-63.

Nguyen, V. H., Nguyen, T. H. T and Nguyen, T. D. P. 2012. A new fish species of the walking snakehead group, the genus Channa (Channidae, Perciformes) in Vietnam. Tap Chi Sinh Hoc. Vietnam J. Biol., 34(2): 158-165.

Peters, W. 1868. Uber die von Hrn. Dr. F. Jagor in dem ostindischen Archipel gesammelten un dem Konigl. Zoologischen Museum ubergebenen Fische. Monatsberichte der 
Koniglich Preussischen, Akademie der Wissenschaften zu Berlin, (4): 254-281.

Praveenraj, J., Uma, A., Knight, J. D. M., Moulitharan, N., Balasubramanian, S., Bineesh, K. K. and Bleher, H. 2018a. Channa quinquefasciata, a new species of snakehead (Teleostei: Channidae) from Torsa River, North Bengal, India. Aqua Int. J. Ichthyol., 24(4): 141-152.

Praveenraj, J., Uma, A., Moulitharan, N. and Bleher, H. 2018 b. Channa bipuli, a new species of snakehead (Teleostei: Channidae) from Assam, north-east India. Aqua Int. J. Ichthyol., 24(4): 153-156.
Taylor, W. R. and Van Dyke, G. C. 1985. Revised procedures for staining and clearing small fishes and other vertebrates for bone and cartilage study. Cybium, 9: 107-119.

Untergasser, A., Cutcutache, I., Koressaar, T., Ye, J., Faircloth, B. C., Remm, M. and Rozen, S. G. 2012. PRIMER 3-new capabilities and interfaces. Nucleic Acids Res., 40(15): p. e115-e115.

Vishwanath, W. and Geetakumari, K. 2009. Diagnosis and interrelationships of fishes of the genus Channa Scopoli (Teleostei: Channidae) of north-eastern India. J. Threat. Taxa, 1(2): 97-105. doi.org/10.11609/jott.o1788.97-105. 